\title{
Probiotics in the Arabian Gulf Region
}

\author{
Abiola C. Senok* \\ Department of Clinical Sciences, College of Medicine, University of Sharjah, Sharjah, United Arab Emirates
}

Abstract

Objective: Available reports on adherence to recommended guidelines for labeling of probiotic products are based on assessment of these products in developed countries. In the Arabian Gulf region, there is a paucity of data on the characterization of probiotic products and an absence of local guidelines for their labeling. This study, carried out in the United Arab Emirates (UAE), represents the first evaluation of probiotic products available in the Arabian Peninsula.

Methods: Probiotic products were purchased over the counter from a variety of sources, including pharmacies, healthfood stores, and supermarkets across the UAE. All identified products were listed and information regarding type of product preparation and labeling information were recorded.

Results: A total of 37 probiotic products, 15 dairy-based and 22 non-dairy-based were identified. The dairy products comprised of 12 yogurts, two fermented milk products and one powdered baby formula. The majority of non-dairy products were in capsule form $(n=16)$. While all the non-dairy products gave information about the strain of probiotic microorganism and number present at time of manufacture, this information was provided for only one dairy-based product. Strains of Lactobacillus acidophilus were the most common probiotic organisms identified. However, one probiotic product listed Enterococcus faecalis (750 million viable bacteria per capsule) as a component. With the exception of one non-dairy-based product, all health-related claims were structure/function statements, according to the US Food and Drug Administration nomenclature.

Conclusion: These findings indicate that a wide variety of probiotic products are available in the Arabian Gulf. Development of guidelines for labeling of these probiotic products and use of structure/function statements and health claims should be addressed.

Keywords: probiotics; lactobacilli; bifidobacterium; health claims

Received: 15 June 2008; Revised: 17 December 2008; Accepted: 20 January 2009; Published 4 March 2009

$\mathrm{P}$ robiotics are defined as live microorganisms that, when administered in adequate amounts, confer beneficial health effects $(1,2)$. In recent years, there has been an upsurge in research into probiotics, as well as growing commercial interest in the probiotic food/food supplement concept. Dairy products, including yogurt, fermented milk products and cheese, remain at the forefront of probiotic food development. Probiotics now constitute a sizeable portion of the functional food market, which continues to show exponential market growth estimated at a staggering $\$ 120$ million per month (3). Yogurts with added live probiotic strains are now available in the marketplace and a number of these products, which have emerged as leaders in the European market, are also marketed internationally.

The commercial exploitation of the probiotic concept is often associated with unsubstantiated claims of beneficial effects. As probiotic products are not considered as drugs, but rather as food supplements, they hitherto have not been subjected to the same rigorous regulations regarding efficacy, quality control, labeling, and consumer information as normally applied to pharmaceutical preparations. In 2002, a Working Group of the FAO/ WHO recommended that the following information be described on the label of probiotic products: genus, species and strain designation, minimum viable numbers of each probiotic strain at the end of the shelf life, suggested serving size to deliver the effective dose of probiotics related to the health claim, health claim(s), proper storage conditions and corporate contact details for consumer information (1). Reports in literature demonstrate that there are differences in the labeling information provided for probiotic products available in different countries with varying degrees of inaccuracies in the information, all of which reflect the lack of international consensus (4-11). However, these reports are based on assessment of probiotic products in developed countries, and so far, there remains a paucity of data on the products available in developing countries and the degree of adherence to the FAO/WHO labeling guidelines in 
these emerging markets (12). This study, carried out in the United Arab Emirates (UAE), represents the first evaluation of probiotic products available in the Arabian Peninsula.

\section{Methods}

Probiotic products were purchased over the counter from a variety of sources, including pharmacies, health food stores, hypermarkets, and supermarkets. All the major hypermarkets, supermarkets, and pharmacy chains with multiple outlets around the country were included, and randomly selected branches were visited over a 10 -week period from January to March 2008. To avoid selection bias, all probiotic products on sale at any given location were purchased. All identified products were listed and information regarding type of product (tablet/capsule, syrup, powdered form, dairy-based products, such as yogurt and fermented milk), type of probiotic strains, number of viable organisms and if this number was guaranteed at time of manufacture and expiry date of product, accuracy of organism identification and spelling were recorded. The health-related claims on each product were recorded.

\section{Results}

Thirty-seven probiotic products were identified, 15 dairybased and 22 non-dairy-based products. The dairy products consisted of 12 yogurt products, two fermented milk products and one powdered baby formula; all were purchased from supermarkets/hypermarkets. Four of the dairy products (Table 1; Nos. 9, 12-14) were manufactured in the region (Saudi Arabia and UAE). The other products were imported from Europe and North America. Five products used 'trademarked' bacterial names to identify the probiotic microorganisms present. An internet search of the 'trademarked' names showed that these represented specific probiotic bacteria strains. Only one dairy product gave information about the strain of probiotic microorganism using the proper scientific name ( $L$. casei shirota), and provided information about the number of microorganisms present at time of manufacture (Table 1). Six products did not list any health-benefit claims. Among the products with healthrelated claims, the most common was improvement of digestive well being and regulation of digestion, using statements like 'promotes general digestive well being' and 'regulates the digestive process'. One product mentioned 'maintenance of favorable balance of bacteria in digestive system and fights harmful bacteria', and 'improved immunity' was listed for two products.

The 22 non-dairy products were obtained from pharmacies and health food stores. The majority of these were capsules (16); others included two preparations in powder form and one each as effervescent tablets, chewable tablets and drinking straws. None of the products had information leaflets as inserts in the package. Ten products $(45 \%)$ provided information on strain identification of all or some of the probiotic microorganisms they contained. A majority of these non-dairy probiotics $(59 \%)$ contained a blend of three to five probiotic microorganisms (Table 2). Lactobacillus bulgaricus and Streptococcus thermophilus, which are culture starters, were listed as probiotic organisms in two products. Enterococcus faecalis (750 million viable bacteria per capsule) was listed as being present in one product. In contrast to the dairy products, all the non-dairy products gave information about the number of bacteria present at the time of manufacture, but none stated how many will be viable at the end of the products shelf life. Nine products did not have any specific health-related claim except for stating that these were food supplements. The beneficial claims listed on the remaining products are shown in Table 2.

\section{Discussion}

After many years of popularity in the Japanese and European markets, probiotic products are now appearing in new markets, including the Arabian Gulf region. The number and diversity of probiotic products available locally is high compared to other regions $(13,14)$. This aptly reflects the increasing level of health awareness and affluence, as well as the cosmopolitan nature of the population. The provision of strain designation of the probiotic organism and minimum viable numbers at the end of the shelf life are important in determining the true efficacy of the health-related claims of these products. None of the studied products fulfilled all these criteria for labeling, set up in the FAO/WHO recommendation (1).

The majority of probiotic products available in this setting contain Lactobacillus and Bifidobacterium, which are the main genera of Gram-positive bacteria currently characterized as probiotics $(15,16)$. However, L. bulgaricus and $S$. thermophilus were found listed as probiotic microorganisms in a number of preparations. It is debatable whether or not these yogurt starter cultures should be considered probiotics $(17,18)$. Although they have been associated with improved lactose digestion and immune enhancement, they fail to fulfill the criteria for a probiotic microorganism, as they are sensitive to conditions in the digestive tract and do not achieve very high numbers in the gut (19). Safety concerns remain about the other genera, such as Escherichia, Enterococcus, and Saccharomyces, which have been marketed as probiotics $(2,20,21)$. It is of concern that one of the non-dairy products contained Enterococcus, which is an important cause of drug-resistant nosocomial infections. Recent work has now demonstrated the transfer of virulence determinants, from medical to food starter strains, in Enterococcus via a natural conjugation process (21). 
Table 1. Characteristics of dairy-based products

\begin{tabular}{|c|c|c|c|c|}
\hline Product no. & Product type & $\begin{array}{l}\text { Types of probiotic } \\
\text { species present }\end{array}$ & Organisms and No. ${ }^{a}$ (per suggested serving) & Claim of beneficial effect \\
\hline 1 & Yogurt & 3 & $\begin{array}{l}\text { L. acidophilus; Bifidus longum; Streptococcus } \\
\text { thermophilus }\end{array}$ & None \\
\hline 2 & Yogurt & Not stated & Not stated & None \\
\hline 3 & Yogurt & Not stated & Not stated & None \\
\hline 4 & Yogurt & 2 & L. acidophilus; L. bifidus & None \\
\hline 5 & Yogurt & Not stated & L. acidophilus; L. bifidus & Promotes general digestive well being \\
\hline 6 & Yogurt & Not stated & Not stated & Healthy digestive system \\
\hline 7 & Fermented milk & 1 & L. casei shirota $10^{\times 10}$ or 6.5 billion per bottle ${ }^{a}$ & Healthy gut immunity \\
\hline 8 & Yogurt & Not stated & NS & None \\
\hline 9 & Yogurt & I & Bifidus essensis ${ }^{\circledR}$ (trademarked) & Regulates the digestive process \\
\hline 10 & Yogurt & Not stated & Bifidus regularis ${ }^{\circledR}$ (trademarked) & Regulates intestinal transit time \\
\hline II & Milk drink & Not stated & Lactobacillus casei defensis ${ }^{\circledR}$ (trademarked) & None \\
\hline 12 & Laban $^{\mathrm{b}}$ & Not stated & Bifidus essensis ${ }^{\circledR}$ (trademarked) & Improves digestion naturally \\
\hline 13 & Laban $^{\text {b }}$ & 1 & Gefilac ${ }^{\circledR}$ (trademarked) & $\begin{array}{l}\text { Maintains favorable balance of bacteria } \\
\text { in digestive system; fights harmful } \\
\text { bacteria }\end{array}$ \\
\hline 14 & Laban $^{\mathrm{b}}$ & 2 & L. acidophilus LA5; B. bifidus $\mathrm{BB} \mid 2$ & Improves digestion, boosts immunity \\
\hline 15 & Baby formula & I & Not stated & None \\
\hline
\end{tabular}

${ }^{a}$ Number present at time of manufacture.

${ }^{\mathrm{b}}$ Traditional yogurt drink in the Middle East.

Inadequate provision of information regarding the bacterial strains present was a problem particularly associated with dairy-based products, where only one product provided the strain identification and number of organisms present, as the beneficial effect attributed to one strain cannot be assumed to be true of another strain even when they are of the same species $(22,23)$. This lack of information makes it difficult for the consumer to objectively evaluate the attributed health-related claims. For $L$. acidophilus, which was the most commonly named probiotic organism, strain identification was only provided in nine products. The beneficial effects of $L$. acidophilus remain inconclusive, but emerging data on specific strains are indicative of a beneficial effect, thus highlighting the importance of strain identification to verify health-related claims $(2,23)$.

Among the products that stated the number of viable organisms, none provided the numbers that would be present at the end of the shelf life, although manufacturing methods and maintenance of proper storage conditions may affect the viability of organisms. In particular, the stability of probiotics in powdered milk (including infant formula) has been questioned, as the production process is known to cause cell damage and loss of viability of the probiotic cultures (24). Thus, from a public health perspective, the number of organisms expected to be viable under normal conditions at the end of the shelf life is of relevance to ensure that the consumer is ingesting an adequate dose of the probiotic. Further work on microbial enumeration of the products available in our setting is recommended.

The two most common health-related claims used were that they maintain healthy intestinal flora and help to improve digestion. Regulations relating to health claims vary in different jurisdictions. In Japan, foods with health claims are categorized into 'Food with Nutrient Function Claims' and 'Food for Specified Health Uses' (FOSHU). The latter contain dietary ingredients that have beneficial effects on the physiological functions of the human body, maintain and promote health, and improve health-related conditions. But claims of disease-risk reduction are, with the exception of calcium and folic acid (25), currently not allowed under FOSHU. In 2007, the European Union introduced a regulation on nutrition and health claims made on foods, which should provide the opportunity for the use of health claims, and in this case include claims of disease-risk reduction (26). In the United States, a healthrelated claim is statutorily defined as a statement that expressly or by implication relates any substance in food or dietary supplement to a disease or health-related condition $(27,28)$. In contrast, structure/function claims are statements regarding the effect of a food or dietary supplement on the structure or function of the body; they cannot address diseases, but may be directed at healthy states $(27,28)$. The level of substantiation needed for structure/function claims is regarded by some regulations 
Table 2. Characteristics of non-dairy-based products

\begin{tabular}{|c|c|c|c|c|}
\hline $\begin{array}{l}\text { Product } \\
\text { no. }\end{array}$ & $\begin{array}{l}\text { Product } \\
\text { type }\end{array}$ & $\begin{array}{l}\text { Types of probiotic } \\
\text { species present }\end{array}$ & Organisms and No. ${ }^{a}$ (per suggested serving) & Claim of beneficial effect \\
\hline 1 & Powder & 4 & $\begin{array}{l}\text { L. acidophilus CUL-2I ( } 6 \text { billion); L. crispatus ( } 500 \\
\text { million); L. rhamnosus ( } 7.5 \text { billion); B. bifidum (I billion); } \\
\text { L. lactis CU-34 (I billion) }\end{array}$ & None \\
\hline 2 & Capsule & 4 & $\begin{array}{l}\text { L. acidophilus CUL-2I ( } 6 \text { billion); L. crispatus ( } 500 \\
\text { million); L. rhamnosus ( } 7.5 \text { billion); B. bifidum (I billion); } \\
\text { L. lactis CU-34 (I billion) }\end{array}$ & None \\
\hline 3 & Capsule & 1 & L. acidophilus ( 2 billion) & None \\
\hline 4 & Capsule & 1 & L. acidophilus (630 million) & None \\
\hline 5 & Capsule & 1 & B. infantis (4 billion) & None \\
\hline 6 & Capsule & 2 & L. acidophilus + B. bifidum (I billion) & None \\
\hline 7 & Drinking straw & 1 & L. acidophilus LA- I4 (500 million) & None \\
\hline 8 & Powder & 3 & $\begin{array}{l}\text { L. acidophilus CLT and CUL-2I ( } 33.3 \text { billion); } L \text {. } \\
\text { bulgaricus CUL- } 66 \text { ( } 33.3 \text { billion); B. bifidum CUL- I } 7 \text { and } \\
\text { CUL-2I ( } 33.3 \text { billion) }\end{array}$ & None \\
\hline 9 & Capsule & 2 & $\begin{array}{l}\text { L. acidophilus LA5 ( } 250 \text { million); B. lactis BBI2 } \\
\text { ( } 250 \text { million) }\end{array}$ & Healthy intestinal flora \\
\hline 10 & Capsule & 4 & $\begin{array}{l}\text { B. lactis BBI2 ( } 1.25 \text { billion); L. acidophilus LA ( } .25 \\
\text { billion); L. paracasei } 43 \text { I (I.25 billion); L. rhamnosus } \\
\text { GG ( } .25 \text { billion) }\end{array}$ & Healthy intestinal flora \\
\hline II & Capsule & 5 & $\begin{array}{l}\text { L. acidophilus LA5 ( } 300 \text { million); L. rhamnosus GG } \\
\text { ( } 300 \text { million); L. casei and L. casei } 43 \text { I ( } 300 \text { million); } \\
\text { S. thermophilus ( } 300 \text { million) }\end{array}$ & Maintain healthy intestinal flora \\
\hline 12 & Powder & 3 & $\begin{array}{l}\text { B. bifidum ( } 350 \text { million); S. thermophilus ( } 350 \text { million); } \\
\text { B. infantis ( } 350 \text { million) }\end{array}$ & Gl support \\
\hline 13 & Capsule & 1 & L. acidophilus LA5 (500 million) & Healthy intestinal flora \\
\hline 14 & Capsule & 4 & $\begin{array}{l}\text { Enterococcus faecalis ( } 750 \text { million); L. acidophilus } \\
\text { ( } 2 \text { billion); B. longum ( } 250 \text { million); B. bifidum } \\
\text { ( } 250 \text { million) }\end{array}$ & Healthy digestion, overall well being \\
\hline 15 & $\begin{array}{l}\text { Chewable } \\
\text { tablets }\end{array}$ & 4 & $\begin{array}{l}\text { Blend of } B \text {. infantis }+B \text {. adolescentis }+B \text {. longum }+ \\
\text { B. bifidum }+B \text {. coagularis ( } \text { billion) }\end{array}$ & Lactic flora accelerant \\
\hline 16 & Capsule & 5 & $\begin{array}{l}\text { Blend of } L \text {. acidophilus }+ \text { L. brevis }+ \text { L. salivarius }+ \\
\text { L. bulgaricus }+ \text { L. bifidus ( } 3 \text { billion) }\end{array}$ & $\begin{array}{l}\text { Supports favorable environment for } \\
\text { nutrients; encourages intestinal flora } \\
\text { balance + promotes healthy functioning } \\
\text { of intestinal system }\end{array}$ \\
\hline 17 & Capsule & 3 & $\begin{array}{l}\text { L. acidophilus ( } 500 \text { million); B. lactis ( } 500 \text { million); } \\
\text { S. thermophilus ( } 500 \text { million) }\end{array}$ & $\begin{array}{l}\text { Maintain healthy digestion; support } \\
\text { microflora in case of inbalance during or } \\
\text { after antibiotics; mild cases of diarrhea }\end{array}$ \\
\hline 18 & $\begin{array}{l}\text { Effervescent } \\
\text { tablets }\end{array}$ & 1 & Lactic acid bacilli $\left(40 \times 10^{6}\right)$ & Maintain healthy intestine \\
\hline 19 & Capsule & 2 & L. acidophilus LA5 + B. infantis (4 billion) & Maintain healthy intestinal flora \\
\hline 20 & Capsule & 4 & $\begin{array}{l}\text { L. acidophilus }+ \text { B. longum }+ \text { B. casei }+ \text { B. infantis } \\
\text { (500 million) }\end{array}$ & None \\
\hline 21 & Capsule & 3 & L. acidophilus $+L$. lactis $+B$. bifidum (I billion) & Maintain healthy intestinal flora \\
\hline 22 & Capsule & 3 & $\begin{array}{l}\text { L. acidophilus CUL-2I ( } 6 \text { billion); L. crispatus } \\
\text { ( } 500 \text { million); L. rhamnosus ( } 7.5 \text { billion); B. bifidum } \\
\text { (I billion); L. lactis CU-34 (I billion) }\end{array}$ & Healthy intestinal flora \\
\hline
\end{tabular}

${ }^{\mathrm{a}}$ Number present at time of manufacture. 
as being significantly lower than that for health claims with respect to the type of studies, limitations of the data and conclusiveness of the findings.

The health-benefit claims made for all but one of these products could be classified as structure-function statements, according to the nomenclature used in the United States. One non-dairy capsule formulation had the statement 'support microflora in case of imbalance during or after antibiotics; useful in mild cases of diarrhea.' This may be regarded as a medicinal claim rather than a health claim, and although B. lactis was listed as being present in this preparation, there was no information on the strain. This makes verification of this claim rather difficult, as this beneficial effect has been demonstrated conclusively for B. lactis BB-12 only (29). In view of the public health implications, there is an urgent need for international regulations to address this worrying trend of using structure/function claims, which places a less stringent onus on manufacturers for the scientific substantiation of these claims. The European Commission supported 'Process for the Assessment of Scientific Support for Claims on Foods', established a defined set of criteria for the scientific substantiation of health claims, a much-needed positive approach (26). These criteria represent a scientifically robust tool, which should be useful in assisting manufacturers in preparing applications for health claims, and provide a reference for regulatory bodies responsible for evaluating the scientific evidence for these claims. In Europe, structure/function claims would fall under the definition of health claims and require the same high level of scientific substantiation, as is the case with the newly introduced EU regulation (26). This report provides the first insight into the availability of probiotic products in the Arabian Pennisula and the findings indicate that a wide variety of products are available. However, the deficiencies in meeting FAO/WHO recommended guidelines and development of local/regional guidelines based on other international models should be addressed. Further work to enumerate the microbial content of these products is recommended.

\section{Conflict of interest and funding}

The author has not received any funding or benefits from industry to conduct this study.

\section{References}

1. FAO/WHO. Report of a joint FAO/WHO expert consultation on guidelines for the evaluation of probiotics in food. London, Ontario, Canada: World Health Organization and Food Agriculture Organization of the United Nations; 2002.

2. Senok AC, Ismaeel AY, Botta GA. Probiotics: facts and myths. Clin Microbiol Infect 2005; 11: 958-66.
3. Stanton C, Gardiner G, Meehan H, Collins K, Fitzgerald G, Lynch PB, et al. Market potential for probiotics. Am J Clin Nutr 2001; 73: 476-484S.

4. Brink M, Senekal M, Dicks LM. Market and product assessment of probiotic/prebiotic-containing functional foods and supplements manufactured in South Africa. S Afr Med J 2005; 95: 114-9.

5. Coeuret V, Gueguen M, Vernoux JP. Numbers and strains of lactobacilli in some probiotic products. Int J Food Microbiol 2004; 97: 147-56.

6. Drisko J, Bischoff B, Giles C, Adelson M, Rao RV, McCallum R. Evaluation of five probiotic products for label claims by DNA extraction and polymerase chain reaction analysis. Dig Dis Sci 2005; 50: 1113-7.

7. Huys G, Vancanneyt M, D'Haene K, Vankerckhoven V, Goossens H, Swings J. Accuracy of species identity of commercial bacterial cultures intended for probiotic or nutritional use. Res Microbiol 2006; 157: 803-10.

8. Saldanha LG. US Food and Drug Administration regulations governing label claims for food products, including probiotics. Clin Infect Dis 2008; 46: S119-21.

9. Theunissen J, Britz TJ, Torriani S, Witthuhn RC. Identification of probiotic microorganisms in South African products using PCR-based DGGE analysis. Int J Food Microbiol 2005; 98: 1121.

10. Weese JS. Microbiologic evaluation of commercial probiotics. J Am Vet Med Assoc 2002; 220: 794-7.

11. Hamilton-Miller JM, Shah S, Winkler JT. Public health issues arising from microbiological and labelling quality of foods and supplements containing probiotic microorganisms. Public Health Nutr 1999; 2: 223-9.

12. Perea Velez M, Hermans K, Verhoeven TL, Lebeer SE, Vanderleyden J, De Keersmaecker SC. Identification and characterization of starter lactic acid bacteria and probiotics from Columbian dairy products. J Appl Microbiol 2007; 103: 666-74.

13. Amagase H. Current marketplace for probiotics: a Japanese perspective. Clin Infect Dis 2008; 46: S73-5.

14. Reid G, Anukam K, Koyama T. Probiotic products in Canada with clinical evidence: what can gastroenterologists recommend? Can J Gastroenterol 2008; 22: 169-75.

15. FAO/WHO. Report of a Joint FAO/WHO Expert Consultation on evaluation of health and nutritional properties of powder milk and live lactic acid bacteria. London, Ontario, Canada: World Health Organization and Food Agriculture Organization of the United Nations; 2001.

16. Holzapfel WH, Haberer P, Geisen R, Bjorkroth J, Schillinger U. Taxonomy and important features of probiotic microorganisms in food and nutrition. Am J Clin Nutr 2001; 73: 365-373S.

17. Pestka JJ, Ha CL, Warner RW, Lee JH, Ustunol Z. Effects of ingestion of yogurts containing Bifidobacterium and Lactobacillus acidophilus on spleen and Peyer's patch lymphocyte populations in the mouse. J Food Prot 2001; 64: 392-5.

18. Tejada-Simon MV, Lee JH, Ustunol Z, Pestka JJ. Ingestion of yogurt containing Lactobacillus acidophilus and Bifidobacterium to potentiate immunoglobulin A responses to cholera toxin in mice. J Dairy Sci 1999; 82: 649-60.

19. de Vrese M, Stegelmann A, Richter B, Fenselau S, Laue C, Schrezenmeir J. Probiotics - compensation for lactase insufficiency. Am J Clin Nutr 2001; 73: 421-29S.

20. Eaton TJ, Gasson MJ. Molecular screening of Enterococcus virulence determinants and potential for genetic exchange between food and medical isolates. Appl Environ Microbiol 2001; 67: 1628-35.

21. Ishibashi N, Yamazaki S. Probiotics and safety. Am J Clin Nutr 2001; 73: 465S-70S. 
22. Ibnou-Zekri N, Blum S, Schiffrin EJ, von der WT. Divergent patterns of colonization and immune response elicited from two intestinal Lactobacillus strains that display similar properties in vitro. Infect Immunol 2003; 71: 428-36.

23. Reid G, Jass J, Sebulsky MT, McCormick JK. Potential uses of probiotics in clinical practice. Clin Microbiol Rev 2003; 16: 65872.

24. Selmer-Olsen E, Sorhaug T, Birkeland SE, Pehrson R. Survival of Lactobacillus helveticus entrapped in Ca-alginate in relation to water content, storage and rehydration. J Ind Microbiol Biotechnol 1999; 23: 79-85.

25. Yamada K, Sato-Mito N, Nagata J, Umegaki K. Health claim evidence requirements in Japan. J Nutr 2008; 138: 1192S-8S.

26. Asp NG, Bryngelsson S. Health claims in Europe: new legislation and PASSCLAIM for substantiation. J Nutr 2008; 138: $1210 \mathrm{~S}-5 \mathrm{~S}$

27. Hasler CM. Health claims in the United States: an aid to the public or a source of confusion. J Nutr 2008; 138: 12165-205.
28. Heimbach JT. Health-benefit claims for probiotic products. Clin Infect Dis 2008; 46: S122-24.

29. Sullivan A, Barkholt L, Nord CE. Lactobacillus acidophilus, Bifidobacterim lactis and Lactobacillus F19 prevent antibioticassociated ecological disturbances of Bacteriodes fragilis in the intestine. J Antimicrob Chemother 2003; 52: 308-11.

*Abiola C. Senok

Department of Clinical Sciences

College of Medicine

University of Sharjah

P.O. Box 27272

Sharjah,

United Arab Emirates

Tel: +97| (6) 5057220

Fax: $+97 \mid(6) 5585879$

Email: asenok@sharjah.ac.ae 